Article

\title{
In Vitro Assessment of Total Phenolic and Flavonoid Contents, Antioxidant and Photoprotective Activities of Crude Methanolic Extract of Aerial Parts of Capnophyllum peregrinum (L.) Lange (Apiaceae) Growing in Algeria
}

\author{
Mostefa Lefahal ${ }^{1}$, Nabila Zaabat ${ }^{1}$, Radia Ayad ${ }^{1}$, El hani Makhloufi ${ }^{1}$, Lakhdar Djarri ${ }^{1}$, \\ Merzoug Benahmed ${ }^{2}$, Hocine Laouer ${ }^{3}$, Gema Nieto ${ }^{4, *}$ (D) and Salah Akkal 1,* (iD \\ 1 Valorization of Natural Resources, Bioactive Molecules and Biological Analysis Unit, \\ Department of Chemistry, University of Mentouri Constantine, Constantine 25000, Algeria; \\ mlefahal@gmail.com (M.L.); z_nabila2002@yahoo.fr (N.Z.); radia.ayad@yahoo.fr (R.A.); \\ makhloufi_el_hani@yahoo.fr (E.h.M.); djarri62@gmail.com (L.D.) \\ 2 Department of Chemistry, Faculty of Science, University of Tebessa, Tebessa 12000, Algeria; \\ Riad43200@yahoo.fr \\ 3 Laboratory of Natural Biological Resources Valorization, Faculty of Sciences, University of Setif, \\ Setif 19000, Algeria; hocine_laouer@yahoo.fr \\ 4 Department of Food Technology, Nutrition and Food Science, Faculty of Veterinary Sciences, \\ University of Murcia, Campus de Espinardo, Espinardo, 30100 Murcia, Spain \\ * Correspondence: gnieto@um.es (G.N.); salah4dz@yahoo.fr (S.A.); \\ Tel.: +34-868-889-624 (G.N.); +213-31-811-102 (S.A.)
}

Received: 17 February 2018; Accepted: 21 March 2018; Published: 22 March 2018

\begin{abstract}
Background: Capnophyllum peregrinum (L.) Lange (Apiaceae) is the unique taxon of capnophyllum genus in Algerian flora. It has never been investigated in regards to its total phenolic and flavonoid contents and antioxidant and photoprotective activities. Methods: C. peregrinum aerial parts extracted with absolute methanol. The total flavonoid and phenolic contents of the extract were evaluated to determine their correlation with the antioxidant and photoprotective activities of the extract. Results: The methanolic extract demonstrated a significant amount of phenolics and flavonoids (74.06 $\pm 1.23 \mathrm{mg} \mathrm{GAE} / \mathrm{g}, 44.09 \pm 2.13 \mathrm{mg} \mathrm{QE} / \mathrm{g}$, respectively) and exhibited good antioxidant activity in different systems, especially in 1,1-Diphenyl-2-picrylhydrazyl (DPPH), reducing power and total antioxidant capacity assays. Furthermore the extract showed high photoprotective activity with the sun protection factor (SPF) value $=35.21 \pm 0.18$. Conclusions: The results of the present study show, that the methanolic extract could be used as a natural sunscreen in pharmaceutics or cosmetic formulations and as a valuable source of natural antioxidants.
\end{abstract}

Keywords: Capnophyllum peregrinum; antioxidant activity; photoprotective activity

\section{Introduction}

Since ancient times, medicinal plants have been used for their medicinal virtues and nutriment values. Presently, the crude extracts from both medicinal and aromatic plants have attracted keen interest in the development and preparation of alternative traditional medicine and food additives [1].

Apiaceae is one of the best-known families of flowering plants, which comprises of about 300-455 genera and 3000-3750 species worldwide [2]. In Algerian flora this family is represented by 55 genera and 130 species [3]. Several Apiaceae members are aromatic plants that are popularly 
used in medicine and in cooking, such as Anethum graveolens, Angelica archangelica, Apium graveolens, Carum carvi, Coriandrum sativum, and Foeniculum vulgare [4]. Capnophyllum Gaertner belongs to the Apiaceae family, which is a genus of small annual herbs, and its name is derived from the Greek (Capnos = smoke, phyllon = leaf) [5]. This genus is represented in the Algerian flora by unique taxon known as Capnophyllum peregrinum (L.) Lange [3]. Concerning the uses of this species, it has been mentioned that its roots are used as vegetables [6]. Regarding the phytochemical investigations on this taxon, only one data item has been published so far, indicating the presence of phtalides, such as Z-ligustilide, in its roots [6].

Natural products from plant sources have the ability to reduce oxidative stress by acting as antioxidants [7]. Hence, plants still present a large source of natural antioxidants that could be taken into account for searching and developing the novel drugs. In fact, phenolic compounds from natural sources are well known as radical scavengers, metal chelators, reducing agents, and hydrogen donors. Thus, plants with high levels of polyphenols have attracted significant importance to be used as natural antioxidants [8].

The ultraviolet radiation is divided into three categories: UV-A (320-400 nm), UV-B (290-320 nm), and UV-C (200-290 nm). The prolonged exposure to these radiations can generate harmful effects which can cause several skin ailments (in particular, UV-B radiation (290-320 nm)) that can cause erythema, sunburns, DNA damage, and premature aging of skin [9]. They also led to the generation of reactive oxygen species (ROS) [10]. Thus, protecting human skin against UV radiation is evident and the effective protection results in the use of formulations containing solar filters (chemicals that absorb UV radiations) known as sunscreens [11]. Recently, plant extracts with antioxidant properties have been used in phytocosmetic field to be used as sunscreens. In fact, that they comprise ingredients that could inactivate ROS and prevent erythema and premature aging of the skin [12].

To find new natural sources which could be used as natural antioxidants and as sunscreens in pharmaceutical or cosmetic preparations, the main aim of this study was to evaluate the in vitro total phenolic and flavonoid contents, antioxidant, and photoprotective activities of crude methanolic extract of aerial parts of $C$. peregrinum growing in Algeria.

\section{Materials and Methods}

\subsection{Plant Materials}

C. peregrinum aerial parts were collected in May 2015 from Elkala (eastern Algerian). The plant was identified by Prof. Dr. H. Laouer from the Department of biology and plant ecology, Ferhat Abbas University (Setif, Algeria) and a voucher specimen were deposited in the Herbarium of our laboratory.

Preparation of Extracts

C. peregrinum aerial parts were dried in a shade at room temperature. A total of $20 \mathrm{~g}$ of dried aerial parts were soaked in absolute methanol in ratio $(1 / 10)$ at room temperature for $72 \mathrm{~h}$. The macerate was filtered using Watman $\mathrm{N}^{\circ} 1$ filter paper. The obtained filtrate was concentrated to dryness under reduced pressure at $40{ }^{\circ} \mathrm{C}$ using a rotary evaporator. The extract is stored at $4{ }^{\circ} \mathrm{C}$ until the experiments were performed [13].

\subsection{Chemicals}

2,2-azinobis-3-ethylbenzothiazoline-6-sulfonic acid (ABTS), 1,1-Diphenyl-2-picrylhydrazyl $(\mathrm{DPPH})$, Potassium ferricyanide $\left[\mathrm{K}_{3} \mathrm{Fe}(\mathrm{CN})_{6}\right]$, Trichloroacetic acid $\left(\mathrm{C}_{2} \mathrm{HCl}_{3} \mathrm{O}_{2}\right)$, Ferric chloride $\left(\mathrm{FeCl}_{3}\right)$, Sodium phosphate $\left(\mathrm{NaH}_{2} \mathrm{PO}_{4}\right)$, Ammonium molybdate $\left(\left(\mathrm{NH}_{4}\right)_{2} \mathrm{MoO}_{4}\right)$, Sulfuric acid, Folin-Ciocalteu, Aluminium chloride $\left(\mathrm{AlCl}_{3}\right)$, Sodium carbonate $\left(\mathrm{Na}_{2} \mathrm{CO}_{3}\right)$, Gallic acid, Quercetin, Ascorbic acid, Butylated hydroxytoluene (BHT), Butylated hydroxyanisole (BHA), $\alpha$-tocopherol were obtained from Sigma Aldrich (St. Louis, MO, USA). All the chemicals used, including the solvents, were of analytical grade. 


\subsubsection{Determination of Total Phenolic Content (TPC)}

Total phenolic content of crude methanolic extract of C. peregrinum was determined by the Folin-Ciocalteu method adopted by Tanguy [14]. A volume of $300 \mu \mathrm{L}$ of extract solution $(1 \mathrm{mg} / \mathrm{mL}$ in methanol) was mixed with $1500 \mu \mathrm{L}$ of Folin-Ciocalteu reagent (diluted 10 fold). After $4 \mathrm{~min}, 1200 \mu \mathrm{L}$ of $\mathrm{Na}_{2} \mathrm{CO}_{3}(75 \mathrm{~g} / \mathrm{L})$ was added. The mixture was incubated at room temperature in the dark for $2 \mathrm{~h}$. The absorbance of the reaction mixture was measured at $765 \mathrm{~nm}$ with UV/VIS spectrophotometer. Gallic acid was used as a standard for calibration curve and results were expressed as Gallic acid equivalents ( $\mu \mathrm{g} \mathrm{GAE} / \mathrm{mg}$ ).

\subsubsection{Determination of Total Flavonoid Content (TFC)}

Total flavonoid content of crude methanolic extract of C. peregrinum was performed by aluminium chloride colorimetric method adopted by Djeridane et al. [15]. A volume of $1 \mathrm{~mL}$ of $2 \% \mathrm{AlCl}_{3}$ ethanol solution was mixed with $1 \mathrm{~mL}$ of sample solution $(1 \mathrm{mg} / \mathrm{mL})$. After incubation for $10 \mathrm{~min}$ at room temperature, the absorbance was measured at $415 \mathrm{~nm}$ with UV/VIS spectrophotometer (Thermo, Waltham, MA, USA). Quercetin was used as a standard for calibration curve and the results were expressed as Quercetin equivalents ( $\mu \mathrm{g} \mathrm{QE} / \mathrm{mg}$ ).

\subsection{In Vitro Antioxidative Activity}

\subsubsection{DPPH Radical Scavenging Assay}

Free radical scavenging activity of crude methanolic extract of C. peregrinum was determined spectrophotometrically according to the modified Blois methods [16]. Forty microliters of crude methanolic extract and standards (BHT, BHA) at various concentrations $(12.5-800 \mu \mathrm{g} / \mathrm{mL})$ were added to $160 \mu \mathrm{L}$ of a methanol solution of DPPH $(0.4 \mathrm{M})$ in a 96 well plate. The mixture was vigorously shaken and then incubated at room temperature for $30 \mathrm{~min}$ in the dark. The absorbance of the mixture was measured at $517 \mathrm{~nm}$ with UV/VIS spectrophotometer. The scavenging activity on the DPPH radical was expressed as inhibition percentage using the following equation:

$$
\% \text { Inhibition }=\left[\left(\mathrm{A}_{\text {control }}-\mathrm{A}_{\text {sample }}\right) / \mathrm{A}_{\text {control }}\right] \times 100
$$

where $A_{\text {control }}$ is the absorbance of the control reaction (containing all reagents except the test extract or standard), and $A_{\text {sample }}$ is the absorbance of the test extract or standard.

\subsubsection{ABTS Radical Scavenging Assay}

The ABTS radical scavenging activity was determined according to the method adopted by Re et al. [17]. The stock solution which was allowed to stand in the dark for $12 \mathrm{~h}$ at room temperature contained equal volumes of $7 \mathrm{mM}$ ABTS salt and $2.4 \mathrm{mM}$ potassium persulfate. The resultant ABTS ${ }^{+}$ solution was diluted with ethanol until an absorbance of $0.708 \pm 0.025$ at $734 \mathrm{~nm}$ was obtained. Forty microliters of varying concentrations $(12.5-800 \mu \mathrm{g} / \mathrm{mL})$ of the crude methanolic extract and standards (BHT, BHA) were allowed to react with $160 \mu \mathrm{L}$ of the $\mathrm{ABTS}^{+}$for $10 \mathrm{~min}$. The absorbance of mixture was recorded at $734 \mathrm{~nm}$ with UV/VIS spectrophotometer.

The scavenging activity on the $\mathrm{ABTS}^{+}$radical was expressed as inhibition percentage using the following equation:

$$
\% \text { Inhibition }=\left[\left(\mathrm{A}_{\text {control }}-\mathrm{A}_{\text {sample }}\right) / \mathrm{A}_{\text {control }}\right] \times 100
$$

where $A_{\text {control }}$ is the absorbance of the control reaction (containing all reagents except the test extract or standard), and $A_{\text {sample }}$ is the absorbance of the extract or standard. 


\subsubsection{Reducing Power Assay}

This assay was performed following the method of Oyaizu [18]. A volume of $1 \mathrm{~mL}$ in different concentrations of crude methanolic extract and standards (BHA, $\alpha$-tocopherol) at various concentrations $(3.125-200 \mu \mathrm{g} / \mathrm{mL}$ ) and $0.75 \mathrm{~mL}$ of distilled water were mixed with $1 \mathrm{~mL}$ of $0.2 \mathrm{M}$ sodium phosphate buffer ( $\mathrm{pH}$ 6.6) and, a volume of $1 \mathrm{~mL}$ of potassium ferricyanide (1\%) was added to the mixture. Following incubation at $50{ }^{\circ} \mathrm{C}$ for $20 \mathrm{~min}$, the reaction mixture was acidified with $1 \mathrm{~mL}$ of trichloroacetic acid $(10 \%)$ and $0.25 \mathrm{~mL}$ of $\mathrm{FeCl}_{3}(0.1 \%)$ was added to this solution. The absorbance was measured at $700 \mathrm{~nm}$ with UV/VIS spectrophotometer.

\subsubsection{Total Antioxidant Capacity by Phosphomolybdenum Method}

Total antioxidant capacity (TAC) of the crude methanolic extract was evaluated by the phosphomolybdenum method according to the procedure described by Prieto et al. [19]. An aliquot $300 \mu \mathrm{L}(2 \mathrm{mg} / \mathrm{mL})$ of crude methanolic extract was added in $3 \mathrm{~mL}$ of reagent solution containing $(0.6 \mathrm{M}$ sulfuric acid, $28 \mathrm{mM}$ sodium phosphate and $4 \mathrm{mM}$ ammonium molybdate). The mixture solution was subjected to incubation in a water bath at $95^{\circ} \mathrm{C}$ for $90 \mathrm{~min}$. The absorbance was measured at $695 \mathrm{~nm}$ with UV/VIS spectrophotometer. The total antioxidant capacity was expressed as Ascorbic acid equivalents ( $\mu \mathrm{g} \mathrm{AAE} / \mathrm{mg}$ ).

\subsection{Photoprotective Activity}

The photoprotective activity of crude methanolic extract was measured by determination in vitro of sun protection factor (SPF), which is considered to be one of the most frequently used indicators for the classification of protection levels afforded by sunscreen products against sunburn due mainly to harmful UV-B radiation [20]. In order to perform the photoprotective activity of $C$. peregrinum aerial parts, the crude methanolic extract was diluted in absolute methanol to obtain a concentration of $2 \mathrm{mg} / \mathrm{mL}$. Spectrophotometric scanning was performed at wavelengths between 290 and $320 \mathrm{~nm}$, with intervals of $5 \mathrm{~nm}$ with UV/VIS spectrophotometer. The readings were performed using $1 \mathrm{~cm}$ quartz cell and methanol used as a blank. SPF value was obtained according to the equation developed by Mansur et al. [21]:

$$
\mathrm{SPF}=\mathrm{CF} \sum_{290}^{320} \mathrm{EE}(\lambda) \mathrm{I}(\lambda) \mathrm{A}(\lambda)
$$

where $\operatorname{EE}(\lambda)$ is the erythemal effect spectrum; $I(\lambda)$ is the solar intensity spectrum; $\operatorname{Abs}(\lambda)$ is the absorbance; and CF is the correction factor $(=10)$.

The values of $\operatorname{EE}(\lambda) \times \mathrm{I}(\lambda)$ (Table 1$)$ are constants, and they were determined by Sayre et al. [22].

Table 1. The Normalized product function used in the calculation of sun protection factor (SPF).

\begin{tabular}{cc}
\hline Wavelength $(\mathbf{n m})$ & EE $\times$ I (Nomalized) \\
\hline 290 & 0.0150 \\
295 & 0.0817 \\
300 & 0.2874 \\
305 & 0.3278 \\
310 & 0.1864 \\
315 & 0.0839 \\
320 & 0.0180 \\
\hline
\end{tabular}

\subsection{Statistical Analysis}

All data were expressed as means \pm SD for at least three replications for each prepared sample. Statistical analysis was performed using one-sample $t$-test. The results are considered to be significant when $p<0.05$. 


\section{Results}

\subsection{Total Phenolic and Flavonoid Content Evaluation}

The total phenolic content of the crude methanolic extract of $C$. peregrinum was estimated by Folin-Ciocalteu reagent and expressed in gallic acid equivalents (GAE) and it was calculated from the linear regression equation of standard curve $\left(y=0.0143 x+0.2567, R^{2}=0.9929\right)$. The results showed that the crude methanolic extract was found to contain a high amount of phenols (74.06 $\pm 1.23 \mu \mathrm{g}$ GAE/mg).

The total flavonoid content of crude methanolic extract was determined via aluminum chloride colorimetric method and it was calculated from the linear regression equation of standard curve of quercetin $\left(y=0.0225 x+0.0078, R^{2}=0.9965\right)$ and expressed as quercetin equivalent per gram of plant extract. The tested extract was found to contain high amounts of flavonoids $(44.09 \pm 2.13 \mu \mathrm{g} Q \mathrm{QE} / \mathrm{mg})$.

\subsection{Antioxidant Activity}

The antioxidant activity is a complex process, usually happening via several mechanisms. Thus evaluation of plant extracts antioxidant activity must be carried out by more than one test [23]. DPPH free radical scavenging, ABTS free radical scavenging, ferric-reducing power and total antioxidant capacity assays were used to evaluate the in vitro antioxidant effect of crude methanolic extract of C. peregrinum.

\subsubsection{DPPH Radical Scavenging Assay}

DPPH free radical scavenging activity of crude methanolic extract is shown in (Table 2). The results reveal that the percentage inhibition of DPPH radical was found to be increased with concentration. The methanolic extract showed maximum activity of $85.21 \pm 0.67 \%$ at $100 \mu \mathrm{g} / \mathrm{mL}$; whereas positive standards, BHT and BHA exhibited $94.00 \pm 0.31 \%$ and $84.18 \pm 0.10 \%$ inhibition respectively. The $\mathrm{IC}_{50}$ value of the extract was determined, and which is defined as the concentration of the extract required to scavenge $50 \%$ of DPPH free radical. Low $\mathrm{IC}_{50}$ value represents high antioxidant activity. In this study the $\mathrm{IC}_{50}$ values of extract and standards (BHT, BHA) were: $48.68 \pm 1.71 \mu \mathrm{g} / \mathrm{mL}, 12.99 \pm 0.41 \mu \mathrm{g} / \mathrm{mL}$ and $6.14 \pm 0.41 \mu \mathrm{g} / \mathrm{mL}$. The results showed that the methanolic extract has a good DPPH radical scavenging effect.

Table 2. Antioxidant activity by the 1,1-Diphenyl-2-picrylhydrazyl (DPPH) assay C. peregrinum methanolic extract.

\begin{tabular}{cccc}
\hline \multirow{2}{*}{ Concentration $\mu \mathrm{g} / \mathrm{mL}$} & \multicolumn{3}{c}{ \% Inhibition in DPPH Assay } \\
\cline { 2 - 4 } & MeOH Extract & BHA & BHT \\
\hline 12.5 & $16.97 \pm 1.06$ & $76.55 \pm 0.48$ & $49.09 \pm 0.76$ \\
25 & $30.26 \pm 2.07$ & $79.89 \pm 0.26$ & $72.63 \pm 2.06$ \\
50 & $53.90 \pm 1.65$ & $81.73 \pm 0.10$ & $88.73 \pm 0.89$ \\
100 & $85.21 \pm 0.67$ & $84.18 \pm 0.10$ & $88.73 \pm 0.89$ \\
200 & $86.63 \pm 0.51$ & $87.13 \pm 0.17$ & $94.97 \pm 0.08$ \\
400 & $86.92 \pm 0.17$ & $89.36 \pm 0.19$ & $95.38 \pm 0.41$ \\
800 & $86.46 \pm 0.19$ & $90.14 \pm 0.00$ & $95.02 \pm 0.23$ \\
\hline IC50 $\boldsymbol{\mu g} / \mathbf{m L}$ & $\mathbf{4 8 . 6 8} \pm \mathbf{1 . 7 1}$ & $\mathbf{6 . 1 4} \pm \mathbf{0 . 4 1}$ & $\mathbf{1 2 . 9 9} \pm \mathbf{0 . 4 1}$ \\
\hline
\end{tabular}

\subsubsection{ABTS Radical Scavenging Assay}

In case of ABTS assay the experimental data (Table 3) reveal that the crude methanolic extract was found to be effective in scavenging the $\mathrm{ABTS}^{+}$radical. The percentage inhibition of $\mathrm{ABTS}^{+}$radical was concentration-dependent. The scavenging effect was $91.91 \pm 0.28 \%$ at higher concentrations $800 \mu \mathrm{g} / \mathrm{mL}$; whereas positive standards BHT and BHA exhibited $96.68 \pm 0.39 \%, 95.86 \pm 0.10 \%$ inhibition respectively. The $\mathrm{IC}_{50}$ values of the extract and the standards BHT and BHA were found to 
be: $63.62 \pm 0.66,1.29 \pm 0.30$ and $1.81 \pm 0.10 \mu \mathrm{g} / \mathrm{mL}$, respectively, this suggests that the tested extract has a weak $\mathrm{ABTS}^{+}$free radical scavenging activity when compared with standards.

Table 3. Antioxidant activity by the 2,2-azinobis-3-ethylbenzothiazoline-6-sulfonic (ABTS) assay C. peregrinum methanolic extract.

\begin{tabular}{cccc}
\hline \multirow{2}{*}{ Concentration $\mu \mathrm{g} / \mathbf{m L}$} & \multicolumn{3}{c}{ \% Inhibition in ABTS Assay } \\
\cline { 2 - 4 } & MeOH Extract & BHA & BHT \\
\hline 12.5 & $5.01 \pm 0.93$ & $69.21 \pm 0.40$ & $92.83 \pm 1.42$ \\
25 & $7.22 \pm 0.47$ & $78.23 \pm 1.34$ & $94.68 \pm 0.42$ \\
50 & $13.85 \pm 0.09$ & $88.12 \pm 1.28$ & $94.95 \pm 0.90$ \\
100 & $28.30 \pm 0.37$ & $88.76 \pm 3.07$ & $95.32 \pm 0.25$ \\
200 & $42.75 \pm 0.43$ & $90.85 \pm 1.74$ & $95.59 \pm 0.47$ \\
400 & $68.36 \pm 0.09$ & $90.95 \pm 0.51$ & $95.83 \pm 0.15$ \\
800 & $91.91 \pm 0.28$ & $96.68 \pm 0.39$ & $95.86 \pm 0.10$ \\
\hline IC50 $\boldsymbol{\mu g} / \mathbf{m L}$ & $\mathbf{6 3 . 6 2} \pm \mathbf{0 . 6 6}$ & $\mathbf{1 . 2 9} \pm \mathbf{0 . 3 0}$ & $\mathbf{1 . 8 1} \pm \mathbf{0 . 1 0}$ \\
\hline
\end{tabular}

\subsubsection{Reducing Power Assay}

The reducing power of the crude methanolic extract was evaluated using ferric to ferrous reducing activity as determined spectrophotometrically from the formation of Perl's Prussian blue colour complex [24]. In our study, the reducing power of the methanolic extract was compared with $\alpha$-Tocopherol and BHA. The results are shown in (Table 4). The results showed that the reducing power activity of the crude methanolic extract increases with the increase in concentrations of the extract solutions. The methanolic extract exhibited $(0.94 \pm 0.02)$ average absorbance at $700 \mathrm{~nm}$ in $200 \mu \mathrm{g} / \mathrm{mL}$ concentration; whereas the positive standards $\alpha$-Tocopherol and BHA exhibited $(1.81 \pm 0.09)(1.86 \pm 0.46)$ average absorbance in the same concentrations.

Table 4. Antioxidant activity by the reducing power assay of C. peregrinum methanolic extract.

\begin{tabular}{cccc}
\hline \multirow{2}{*}{ Concentration $\mu \mathrm{g} / \mathrm{mL}$} & \multicolumn{3}{c}{ Absorbance } \\
\cline { 2 - 4 } & MeOH Extract & BHA & $\boldsymbol{\alpha}$-Tocopherol \\
\hline 3.125 & $0.08 \pm 0.01$ & $0.28 \pm 0.02$ & $0.11 \pm 0.00$ \\
6.25 & $0.09 \pm 0.01$ & $0.54 \pm 0.02$ & $0.16 \pm 0.00$ \\
12.5 & $0.13 \pm 0.01$ & $0.75 \pm 0.07$ & $0.21 \pm 0.03$ \\
25 & $0.19 \pm 0.02$ & $1.28 \pm 0.28$ & $0.35 \pm 0.03$ \\
50 & $0.29 \pm 0.03$ & $1.49 \pm 0.11$ & $0.73 \pm 0.03$ \\
100 & $0.58 \pm 0.04$ & $1.79 \pm 0.16$ & $1.37 \pm 0.08$ \\
200 & $0.94 \pm 0.02$ & $1.86 \pm 0.46$ & $1.81 \pm 0.09$ \\
\hline
\end{tabular}

\subsubsection{Total Antioxidant Capacity by Phosphomolybdenum Method}

Total antioxidant capacity of crude methanolic extract of C. peregrinum was evaluated by the phosphomolybdenum method and was expressed as ascorbic acid equivalent per mg of plant extract. The results reveal that the crude methanolic extract was found to possess strong total antioxidant capacity $(130.91 \pm 4.40 \mu \mathrm{g}$ AAE/mg).

\subsection{Photoprotective Activity}

The photoprotective activity of the crude methanolic extract was evaluated by calculation of SPF; the SPF parameter was determined by the spectrophotometric method developed by Mansur et al. [21], using the UV-B region, considered to be the region of greatest incidence during the day in which people are exposed for longer [10], in this way it has been reported that in SPF ratings, SPF values 2-12, $12-30$ and $\geq 30$ are considered as having respectively minimum, moderate and high sun protective 
activity [25]. As shown in experimental data (Table 5) the extract showed high absorbance values ranged between 3.45 and 3.58 at $290-320 \mathrm{~nm}$, and the SPF value was found to be $35.21 \pm 0.18$. The results indicate that the methanolic extract have displayed high photoprotective activity.

Table 5. Photoprotective activity of C. peregrinum methanolic extract.

\begin{tabular}{ccc}
\hline Wavelength $(\mathbf{n m})$ & EE $\times \mathbf{I}$ & Absorbance \\
\hline 290 & 0.0150 & $3.583 \pm 0.011$ \\
295 & 0.0817 & $3.561 \pm 0.026$ \\
300 & 0.2874 & $3.53 \pm 0.011$ \\
305 & 0.3278 & $3.52 \pm 0.036$ \\
310 & 0.1864 & $3.484 \pm 0.02$ \\
315 & 0.0839 & $3.478 \pm 0.039$ \\
320 & 0.0180 & $3.453 \pm 0.03$ \\
\hline $\mathrm{SPF}=\mathrm{CF} \sum_{290}^{320} \mathrm{EE}(\lambda) \mathrm{I}(\lambda) \mathrm{A}(\lambda)=35.21 \pm 0.18$ \\
\hline
\end{tabular}

\section{Discussion}

In the present study, phenolic and flavonoid composition as well as antioxidant and photoprotective activities of Capnophyllum peregrinum were investigated the first time in an attempt to unravel new possible uses of this plant. Concerning total phenolic and flavonoid contents, the results suggest that phenolics and flavonoids are important components of the crude methanolic extract. These results are in accordance with previous findings reported in other Apiaceae species extracted with methanol such as Prangos ferulacea Lindl, Prangos meliocarpoides Boiss and Prangos uechtritzii Boiss. \& Hausskn [26], Pituranthos chloranthus Benth and Hook [13]. Because of polyphenols are linked to the cell-wall matrix through a glycosidic/ester linkage, their water solubility may be reduced [27]. Thus several authors displayed that alcohols are suitable solvents for the extraction of phenolic and flavonoids compounds. For example, methanol or ethanol are mostly used for the separation of this class of natural products [28] according to their best solubility in alcohols, particularly in methanol [13]. Also, it has been observed that methanolic extracts of medicinal plants exhibited high phenolic and flavonoids contents as well as antioxidant activities more than water, ethyl acetate, chloroform and acetone extracts $[13,29,30]$. From literature, it has been well noted that medicinal plants with high amounts of phenols and flavonoids have potent antioxidant actions [31-34]. This may explain the antioxidant activity of C. peregrinum. In term of DPPH-scavenging potential of methanolic extract, our results are in accordance with those of previous works, indicating close relationship between DPPH radical scavenging effect and total phenolic and flavonoid contents of Apiaceae species such as Ammi majus L. [35], Ferula gummosa Boiss [36], Daucus carota Linn [37], Sesili libanotis (L.) Koch, Sesili libanotis (L.) Koch [38], Coriandrum sativum [39], Foeniculum vulgare, Anethum graveolens [40]. Concerning the reducing power and the total antioxidant capacity, the effectiveness of the methanolic extract may be explained by its high phenol and flavonoid contents. In this context, the results of our investigation are in accordance with those published earlier, which mentioned that containing flavonoids and polyphenols may play an important role in reducing power [7] and they contribute significantly to the total antioxidant activity of many fruits such as red grape [41], Star Apple [42] and medicinal plants [43].

In case of photoprotective activity, it has been well mentioned that flavonoids have significant photoprotective effects because of their UV absorbing capacity and their antioxidants effects [44]. Thus, some flavonoids such as quercetin, kaempferol, galanin and apigenin have been evaluated for their photoprotective activity [9]. Recently, it is well reported that plant extracts rich in flavonoids are capable of absorbing ultraviolet light in the UV-B and UV-A regions [11]. In this context, several authors have associated the photoprotective activity of plant extracts with their flavonoids content [45-47]. Thus the photoprotective potential of the methanolic extract of $C$. peregrinum could be explained by its flavonoids content. Indeed, it has been reported that UV-B rays absorbed by the skin led to the 
production of aggressive free radicals such as $\left(\mathrm{O}_{2},{ }^{1} \mathrm{O}_{2}, \mathrm{HO}_{2}, \mathrm{OH}, \mathrm{ROO}\right)$ [48]. Hence, the incorporation of antioxidants is now widely recommended in sunscreens. In this context, it also has been reported that the evaluation of most effective extracts for the antioxidant activity would be important for the development of more effective sunscreens [49]. Since, the methanolic extract exhibited antioxidant effects, is having a possibility to be used as sunscreen in pharmaceutics or cosmetics formulations.

\section{Conclusions}

In conclusion, our study evaluates, for the first time, total phenolic and flavonoid contents in addition to antioxidant and photoprotective activities of aerial parts of Capnophyllum peregrinum (L.) Lange (Apiaceae) growing in Algeria, our findings revealed that the methanolic extract was found to have a high phenolic and flavonoid contents as well as antioxidant and photoprotective activities. Therefore, it appears to be used a sunscreen in pharmaceutical or cosmetic preparations and as a natural source of antioxidant. Also, it can be speculated that the findings of our work could make the background for further investigation of this species, especially research concerning individual phenolic compounds.

Acknowledgments: The authors gratefully acknowledge the Ministry of Higher Education and Scientific Research, Algeria, for financial support.

Author Contributions: Mostefa Lefahal, Nabila Zaabat, Radia Ayad and El hani Makhloufi contributed to the experiments. Lakhdar Djarri and Merzoug Benahmed contributed to the data handling. Hocine Laouer contributed for the botanical identification of the plant. Salah Akkal and Gema Nieto contributed for the writing of the paper.

Conflicts of Interest: The authors report no financial or nonfinancial conflict of interest. The authors alone are responsible for the content and writing of the paper.

\section{References}

1. Amzad, H.M.; Al-Rakmi, K.A.S.; Al-Mijizy, Z.H.; Weli, A.M.; Al-Riyami, Q. Study of total phenol, flavonoids contents and phytochemical screening of various leaves crude extracts of locally grown Thymus vulgar. Asian Pac. J. Trop. Biomed. 2013, 3, 705-710.

2. Lamamra, M.; Laouer, H.; Amira, S.; Ilkay, E.O.S.; Sezer, S.F.; Demereci, B.; Akkal, S. Chemical Composition and Cholinesterase Inhibitory Activity of Different Parts of Daucus aristidis Coss. Essential Oils from Two Locations in Algeria. Rec. Nat. Prod. 2017, 11, 147-156.

3. Quezel, P.; Santa, S. New flora of Algeria and southern desert regions. J. Agric. Trop. Bot. Appl. 1965, 12, 784.

4. El-Kolli, M.; Laouer, H.; El-Kolli, H.; Akkal, S.; Sahli, F. Chemical analysis, antimicrobial and anti-oxidative properties of Daucus gracilis essential oil and its mechanism of action. Asian Pac. J. Trop. Biomed. 2016, 6, 8-15. [CrossRef]

5. Magee, A.R.; Van Wyk, B.E.; Tilney, P.M.; Downie, S.R. A taxonomic revision of Capnophyllum (Apiaceae: Apioideae). S. Afr. J. Bot. 2009, 75, 283-291. [CrossRef]

6. Gijbels, M.J.M.; Fischer, F.C.; Scheffer, J.J.C.; Baerheim Svendsen, A. Phthalides in Roots of Capnophyllum peregrinum and Peucedanum ostruthium. Planta Med. 1984, 50, 110. [CrossRef] [PubMed]

7. Ghribia, L.; Ghouilaa, H.; Omrib, A.; Besbesb, M.; Ben Janneta, H. Antioxidant and anti-acetylcholinesterase activities of extracts and secondary metabolites from Acacia cyanophylla. Asian Pac. J. Trop. Biomed. 2014, 4 (Suppl. 1), S417-S423. [CrossRef] [PubMed]

8. Senthilkumar, R.; Parimelazhagan, T.; Chaurasia, O.P.; Srivastava, R.B. Free radical scavenging property and antiproliferative activity of Rhodiola imbricata Edgew extracts in HT-29 human colon cancer cells. Asian Pac. J. Trop. Med. 2013, 6, 11-19. [CrossRef]

9. Stevanato, R.; Bertelle, M.; Fabris, S. Photoprotective characteristics of natural antioxidant polyphenols. Regul. Toxicol. Pharmacol. 2014, 69, 71-77. [CrossRef] [PubMed]

10. De-Oliveira-Junior, R.G.; Ferraz, C.A.A.; Souza, G.R.; Leite Guimaraes, A.; Paula de Oliveira, A.; Gomes de Lima-Saraiva, S.R.; Araújo Rolim, L.; José Rolim-Neto, P.; Guedes da Silva Almeida, J.R. Phytochemical analysis and evaluation of antioxidant and photoprotective activities of extracts from flowers of Bromelia laciniosa (Bromeliaceae). Biotechnol. Biotechnol. Equit. 2017, 31, 600-605. [CrossRef] 
11. Costa, S.C.C.; Detoni, C.B.; Branco, C.R.C.; Botura, M.B.; Branco, A. In vitro photoprotective effects of Marcetia taxifolia ethanolic extract and its potential for sunscreen formulations. Rev. Bras. Farmacogn. 2015, 25, 413-418. [CrossRef]

12. Reis Mansura, M.C.P.P.; Leitaoa, S.G.; Cerqueira-Coutinhoa, C.; Vermelhob, A.B.; Silva, R.S.; Presgravec, O.A.F.; Leitaod, A.A.C.; Leitaoe, G.G.; Ricci-Juniora, E.; Santosa, E.P. In vitro and in vivo evaluation of efficacy and safety of photoprotective formulations containing antioxidant extracts. Rev. Bras. Farmacogn. 2016, 26, 251-258. [CrossRef]

13. Khettaf, A.; Belloula, N.; Dridi, S. Antioxidant activity, phenolic and flavonoid contents of some wild medicinal plants in southeastern Algeria. Afr. J. Biotechnol. 2016, 15, 524-530.

14. Tanguy, J. Phenol metabolism and the hypersensitive reaction in Nicotiana infected with tobacco mosaic virus. Physiol. Veg. 1971, 9, 169-187.

15. Djeridane, A.; Yous, M.; Nadjemi, B.; Boutassouna, D.; Stocker, P.; Vidal, N. Antioxidant activity of some Algerian medicinal plants extracts containing phenolic compounds. Food Chem. 2006, 97, 654-660. [CrossRef]

16. Blois, M.S. Antioxidant determinations by the use of a stable free radical. Nature 1958, 181, 1199-1200. [CrossRef]

17. Re, R.; Pellegrini, N.; Proteggente, A.; Pannala, A.; Yang, M.; Rice-Evans, C. Antioxidant activity applying an improved ABTS radical cation decolorization assay. Free Radic. Biol. Med. 1999, 26, 1231-1237. [CrossRef]

18. Oyaizu, M. Studies on products of browning reactions: Antioxidative activities of browning reaction prepared from glucosamine. Jpn. J. Nutr. 1986, 44, 307-315. [CrossRef]

19. Prieto, P.; Pineda, M.; Aguilar, M. Spectrophotometric Quantitation of Antioxidant Capacity through the Formation of a Phosphomolybdenum Complex: Specific Application to the Determination of Vitamin E1. Anal. Biochem. 1999, 269, 337-341. [CrossRef] [PubMed]

20. Miksa, S.; Lutz, D.; Guy, C. New approach for a reliable in vitro sun protection factor method Part I: Principle and mathematical aspects. Int. J. Cosmet. Sci. 2015, 37, 555-566. [CrossRef] [PubMed]

21. Mansur, J.S.; Breder, M.V.R.; Mansur, M.C.A. Determinacao do fator de protecao solar por espectrofotometria. An. Bras. Dermatol. 1986, 61, 121-124.

22. Sayre, R.M.; Agin, P.P.; Levee, G.J.; Marlowe, E. A comparison of in vivo and in vitro testing of sunscreening formulas. Photochem. Photobiol. 1979, 29, 559-566. [CrossRef] [PubMed]

23. El Jemli, M.; Kamal, R.; Marmouzi, I.; Doukkali, Z.; Bouidida, E.H.; Touati, D.; Nejjari, R.; El Guessabi, L.; Cherrah, Y.; Alaoui, K. Chemical composition, acute toxicity, antioxidant and anti-inflammatory activities of Moroccan Tetraclinis articulata L. J. Tradit. Complement. Med. 2017, 7, 281-287. [CrossRef] [PubMed]

24. Hossain, M.D.I.; Sharmin, F.A.; Akhter, S.; Bhuiyan, M.A.; Shahriar, M. Investigation of cytotoxicity and in-vitro antioxidant activity of Asparagus racemosus root extract. Int. Curr. Pharm. J. 2012, 1, 250-257. [CrossRef]

25. Ratnasooriya, W.D.; Pathirana, R.N.; Dissanayake, A.S.; Samanmali, B.L.C.; Desman, P.K. Evaluation of in vitro sun screen activities of salt marshy plants Suaeda monoica, Suaeda maritima and Halosarcia indica. Int. J. Pharm. Res. Allied Sci. 2016, 5, 15-20.

26. Ahmed, J.; Guvenec, A.; Kucukboyaci, N.; Baldemir, A.; Coskun, M. Total phenolic contents and antioxidant activities of Prangos Lindl. (Umbelliferae) species growing in Konya province (Turkey). Turk. J. Biol. 2011, 35, 353-360.

27. Rasouli, H.; Hosein-Farzaei, M.; Khodarahmi, R. Polyphenols and their benefits: A review. Int. J. Food Prop. 2017, 20, S1700-S1741. [CrossRef]

28. Ignat, I.; Volf, I.; Popa, V.I. A critical review of methods for characterisation of polyphenolic compounds in fruits and vegetables. Food Chem. 2011, 126, 1821-1835. [CrossRef] [PubMed]

29. Tripathi, Y.C.; Jhumka, Z.; Anjum, N. Evaluation of Total Polyphenol and Antioxidant Activity of Leaves of Bambusa nutans and Bambusa vulgaris. J. Pharm. Res. 2015, 9, 271-277.

30. Nino, J.; Anjum, N.; Tripathi, Y.C. Phytochemical screening and evaluation of polyphenols, flavonoids and antioxidant activity of Prunus cerasoids. D. Don leaves. J. Pharm. Res. 2016, 10, 502-508.

31. Dehshiri, M.M.; Aghamollaei, H.; Zarini, M.; Nabavi, S.M.; Mirzaei, M.; Loizzo, M.R.; Nabavi, S.F. Antioxidant activity of different parts of Tetrataenium lasiopetalum. Pharm. Biol. 2013, 51, 1081-1085. [CrossRef] [PubMed]

32. Da Silva, J.F.M.; De Souza, M.C.; Matta, S.R. Correlation analysis between phenolic levels of Brazilian propolis extracts and their antimicrobial and antioxidant activities. Food Chem. 2006, 99, 431-435. [CrossRef] 
33. Ksouri, R.; Falleh, H.; Megdiche, W.; Trabelsi, N.; Mhamdi, B.; Chaieb, K.; Bakrouf, A.; Magné, C.; Abdelly, C. Antioxidant and antimicrobial activities of the edible medicinal halophyte Tamarix gallica L. and related polyphenolic constituents. Food Chem. Toxicol. 2009, 47, 2083-2091. [CrossRef] [PubMed]

34. Falleh, H.; Medini, F.; Ksouri, R.; Guyot, S.; Abdelly, C.; Magné, C. Antioxidant activity and phenolic composition of the medicinal and edible halophyte Mesembryanthemum edule L. Ind. Crops Prod. 2011, 34, 1066-1071. [CrossRef]

35. Al-Hadhrami, R.M.S.; Hossain, M.A. Evaluation of antioxidant, antimicrobial and cytotoxic activities of seed crude extracts of Ammi majus grown in Oman. Egypt. J. Basic Appl. Sci. 2016, 3, 329-334. [CrossRef]

36. Ebrahimzadeh, M.A.; Nabavi, S.M.; Nabavi, S.F.; Dehbour, A.A. Antioxidant activity of hydroalcoholic extract of Ferula gummosa Boiss roots. Eur. Rev. Med. Pharm. Sci. 2011, 15, 658-664.

37. Chatatikun, M.; Chiabchalard, A. Phytochemical screening and free radical scavenging activities of orange baby carrot and carrot (Daucus carota Linn.) root crude extracts. J. Chem. Pharm. Res. 2013, 5, 97-102.

38. Matejić, J.S.; Džamić, A.M.; Mihajilov-Krstev, T.; Ranđelović, V.N.; Krivošej, Z.D.; Marin, P.D. Total phenolic content, flavonoid concentration, antioxidant and antimicrobial activity of methanol extracts from three Seseli L. taxa. Cent. Eur. J. Biol. 2012, 7, 1116-1122.

39. Shah, M.R.; Satardekar, K.V.; Barve, S.S. Screening of phenolic content, antioxidant and in vitro eye irritation activities from Apiaceae family (dry seeds) for potential cosmetic applications. Int. J. Pharm. Sci. Res. 2014, 5, 4366-4374.

40. Bagdassarian, V.L.C.; Bagdassarian, K.S.; Atanassova, M.S. Phenolic profile, antioxidant and antimicrobial activities from Apiaceae family (dry seeds). Mintage J. Pharm. Med. Sci. 2013, 2, 26-31.

41. Negro, C.; Tommasi, L.; Miceli, A. Phenolic compounds and antioxidant activity from red grape marc extracts. Bioresour. Technol. 2003, 87, 41-44. [CrossRef]

42. Luo, X.D.; Basile, M.J.; Kennelly, E.J. Polyphenolic antioxidants from the fruits of Chrysophyllum cainito L. (star apple). J. Agric. Food Chem. 2002, 50, 1379-1382. [CrossRef] [PubMed]

43. Bourgou, S.; Ksouri, R.; Bellila, A.; Skandrani, I.; Falleh, H.; Marzouk, B. Phenolic composition and biological activities of Tunisian Nigella sativa L. shoots and roots. C. R. Biol. 2008, 331, 48-55. [CrossRef] [PubMed]

44. Saewan, N.; Jimtaisong, A. Photoprotection of natural flavonoids. J. Appl. Pharm. Sci. 2013, 3, $129-141$.

45. Souza, M.S.K.; Dos Santos, A.T.; Alves, F.C.A.; Paula, O.A.; Almeida, A.V.; Alves, S.F.J.; Cavalcante da Cruz, A.E.; Guedes da Silva, A.J.R.; Darklei Santos, S.N.; Pereira, N.X. Identification of flavonol glycosides and in vitro photoprotective and antioxidant activities of Triplaris gardneriana Wedd. J. Med. Plants Res. 2015, 9, $207-215$.

46. Silva, E.E.S.; Alencar-Filho, J.M.T.; Oliviera, A.P.; Guimaraes, A.L.; Iqueira-Filho, J.A.; Almeida, J.R.G.S.; Araujo, E.C.C. Identification of glycosil flavones and determination in vitro of antioxidant and photoprotective activities of Alternanthera braziliana L. Kuntze. Res. J. Phytochem. 2014, 8, 148-154.

47. De-Oliveira-Junior, R.G.; Souza, G.R.; Guimarães, A.L.; Paula de Oliveira, A.; Silva Morais, A.C.; Araújo, E.C.C.; Nunes, X.P.; Almeida, J.R.G.S. Dried extracts of Encholirium spectabile (Bromeliaceae) present antioxidant and photoprotective activities in vitro. J. Young Pharm. 2013, 5, 102-105. [CrossRef] [PubMed]

48. Ratnasooriya, W.D.; Chandra-Jayakody, J.R.A.; Denzil-Rosa, S.R.; Ratnasooriya, C.D.T. In vitro sun screening activity of Sri Lankan orthodox black tea (Camellia sinensis linn). World J. Pharm. Sci. 2014, 2, 144-148.

49. Napagoda, M.T.; Shamila, B.M.A.M.; Abayawardana, S.A.K.; Qader, M.M.; Jayasingh, L. Photoprotective potential in some medicinal plants used to treat skin diseases in Sri Lanka. BMC Complement. Altern. Med. 2016, 16, 479. [CrossRef] [PubMed]

(C) 2018 by the authors. Licensee MDPI, Basel, Switzerland. This article is an open access article distributed under the terms and conditions of the Creative Commons Attribution (CC BY) license (http:/ / creativecommons.org/licenses/by/4.0/). 